\title{
Infections, reproductive health, non - communicable diseases and health systems dominate articles in this June issue of African Health Sciences.
}

\author{
James K Tumwine
}

DOI: https://dx.doi.org/10.4314/ahs.v17i2.1

Cite as: Tumwine JK. Infections, reproductive health, non - communicable diseases and health systems dominate articles in this June issue of African Health Sciences. Afri Health Sci; 2017; 2: i-iiii. doi:https:// dx.doi.org/10.4314/ahs.v17i2.1

Infections: Ugandan researchers report on the burden, and factors contributing to peri-portal fibrosis in HIV-infected patients in a bilharzia endemic area in Uganda ${ }^{1}$. They report a very high prevalence of $S$. mansoni and periportal fibrosis, especially among the not so young. Still with HIV, Nigerian authors ${ }^{2}$ share with us their findings on the effect of vitamins $A$ and $C$ supplementation on oxidative stress in HIV and HIV-TB co-infection in Lagos, while their country folk muse over opportunistic infections among patients with $\mathrm{HIV}^{3,4}$. A study on risk factors for superficial fungal infections in school children is of interest to parents and those concerned with schools, adolescents and public health ${ }^{5}$. Researchers from South Africa refresh us with findings of their study on the effect of smoking on acute phase reactants, stress hormone responses and vitamin $\mathrm{C}$ in pulmonary tuberculosis. Very relevant information as countries, communities and individuals struggle with the dangers of smoking. ${ }^{6}$

The emergence of anti-microbial resistance has reached epidemic proportions, with its obvious threat to lives of millions worldwide. We bring you work from Tunisia on dissemination and genetic support of broad-spectrum beta-lactam-resistant Escherichia coli strain isolated from two hospitals. A must read. ${ }^{7}$ A similar article by Alabi and colleagues ${ }^{8}$ on molecular screening of antibiotic-resistant determinants among multidrug-resistant clinical isolates of Proteus mirabilis from Southwest Nigeria also makes interesting reading.

We conclude this infectious diseases section with two interesting papers: osteopontin as a marker for response to pegylated interferon Alpha-2b treatment in chronic HCV Saudi patients ${ }^{9}$, and a VAR2CSA: CSP conjugate malaria vaccine capable of inducing dual specificity antibody responses $^{10}$.
Reproductive bealth: Now our launch into reproductive health issues. From Iran we have a very interesting article on sexual health education among engaged couples ${ }^{11}$. The authors identified predominant themes: socio-cultural changes; social pathologies; limited sexual knowledge; challenges in sexual health services provision; individual and social consequences.

Articles from Nigeria ${ }^{12}$ and Malawi ${ }^{13}$ shed some light on the determinants of universal access to antenatal and natal health services. From the Gambia, we have a study on the uptake of long-acting reversible contraceptive devices with Depo Provera, and implants as the most commonly used ${ }^{14}$. We conclude this section with a controversial but disturbing article ${ }^{15}$ on 'evidence for decreasing sperm count in African population from 1965 to 2015.'

Non communicable diseases and conditions: Now over to non-communicable diseases. South African scientists ${ }^{16}$ report on allostatic load and heart rate variability as health risk indicators while from Turkey, we have a report on sleep disorders among older adults. ${ }^{17}$

There is a dearth of data on mineral and bone disorders in patients with chronic kidney disease in sub-Saharan Africa. Bala and colleagues report that secondary hyperparathyroidism and 25-OH vitamin $\mathrm{D}$ deficiency were common in haemodialysis patients; and that hypocalcaemia and hyperphosphataemia were strong predictors of secondary hyperparathyroidism. ${ }^{18}$

The rest of the NCD articles are on: changes in mediators of inflammation and pro-thrombosis after 12 months of dietary modification in adults with metabolic syndrome ${ }^{19}$; factors associated with peripheral neuropathy among newly diagnosed Ugandan diabetic patients ${ }^{20}$ and miR126 as a novel biomarker for coronary artery disease ${ }^{21}$. 
Health systems: From Northern Uganda, we have a report on assessment of hospital-based adult triage at emergency receiving areas. Opiro and colleagues found that very few hospitals had formal adult hospital-based triage, with staff performing subjective "eyeball" judgments ${ }^{22}$. Most countries in Africa and the Middle East have a mobile telephone penetration of over 70\%. United Arab Emirates researchers studied distraction-related road traffic collisions $^{23}$. They found that about 40 percent of the distracted drivers involved in road traffic collisions were using mobile phones. The time for action is now!

Ugandan researchers report on the effect of low-dose ketamine on post-operative serum IL-6 production among elective surgical patients ${ }^{24}$; while Nigerian surgeons share their experience with major limb amputations in a tertiary hospital ${ }^{25}$. Trauma and diabetic foot gangrene were the commonest reason - with road traffic accidents and subsequent mismanagement by traditional bone setters as the culprits.

Next we have diverse, but interesting articles on: disordered eating attitudes ${ }^{26}$; lifestyle factors influencing bone health in young women in Saudi Arabia ${ }^{27}$; and secular trend of the leading causes of death in China. Cancer and cerebrovascular disease accounted for more than $67 \%$ of all deaths ${ }^{28}$. Thinking of mortality: it seems that family type and domestic violence were significant predictors of under-five children mortality in Nigeria ${ }^{29}$.

In an innovative study of near vision spectacle coverage and barriers to near vision correction among adults in Ghana, Ntodie and others found that there was a $64 \%$ unmet need for vision correction in the entire study population, with cost being prohibitive. ${ }^{30}$

Now into the realm of therapentics. Two articles tackle the issue of epilepsy. One is on the use of modified Atkins diet for treating epilepsy in low and middle income countries $^{31}$, while the other is on vitamin B6, and homocysteine levels in carbamazepine treated epilepsy patients ${ }^{32}$. The other therapeutics paper reports on antitumor activity of camptothecin, from endophytic fungus Fusarium solani isolated from Camptotheca acuminate. ${ }^{33}$

\section{Other issues}

These include: psychosocial health challenges of the elderly in Nigeria ${ }^{34}$; responsible conduct of research ${ }^{35}$; and effects of economic and security challenges on the Nigerian health sector. ${ }^{36}$.

African Health Sciences Vol 17 Issue 2, June, 2017
Several case reports and a letter conclude our menu of articles in this issue: recovery from severe dysphagia in systemic sclerosis ${ }^{37}$; and humidity as an ambient parameter to development of Zika virus ${ }^{38}$. We end where we started: infections with an article on the emerging epidemic of drug resistant tuberculosis in vulnerable populations of low income countries. ${ }^{39}$

Take your time and enjoy this bumper collection of very interesting articles relevant to the health and people of Africa and beyond. All for free!

\section{References}

1. Ocama P, Opio KC, Seremba E, Ajal P, Apica BS, Aginya EO. The burden, pattern and factors that contribute to periportal fibrosis in HIV-infected patients in an S. mansoni endemic rural Uganda. Afri Health Sci. 2017;17(2): 301-307. https://dx.doi.org/10.4314/ahs.v17i2.2

2. Makinde O, Rotimi K, Ikumawoyi V, Adeyemo T, Olayemi S. Effect of vitamin A and vitamin C supplementation on oxidative stress in HIV and HIV-TB co-infection at Lagos University Teaching Hospital (LUTH) Nigeria. Afri Health Sci. 2017;17(2): 308-314. https://dx. doi.org/10.4314/ahs.v17i2.3

3. Akinyemi JO, Ogunbosi BO, Fayemiwo AS, Adesina OA, Obaro M, Kuti MA, Awolude OA, Olaleye DO, Adewole IF. Demographic and epidemiological characteristics of HIV opportunistic infections among older adults in Nigeria. Afri Health Sci. 2017;17(2): 315-321. https:/ / dx.doi.org/10.4314/ahs.v17i2.4

4. Awoyeni A, Olaniran O, Odetoyin B, Hassan-Olajokun R, Olopade B, Afolayan D, Adekunle O. Isolation and evaluation of Candida species and their association with CD4+ $\mathrm{T}$ cells counts in HIV patients with diarrhoea. Afri Health Sci. 2017;17(2): 322-329. https://dx.doi. org/10.4314/ahs.v17i2.5

5. Olutoyin OO, Onayemi O, Gabriel AO. Risk factors associated with acquiring superficial fungal infections in school children in South Western Nigeria: a comparative study. Afri Health Sci. 2017;17(2): 330-336. https://dx.doi. org/10.4314/ahs.v17i2.6

6. Opolot JO, Theron AJ, MacPhail P, Feldman C, Anderson R. Effect of smoking on acute phase reactants, stress hormone responses and vitamin $C$ in pulmonary tuberculosis. Afri Health Sci. 2017;17(2): 337-345. https:/ / dx.doi.org/10.4314/ahs.v17i2.7

7. Ayari K, Bourouis A, Chihi H, Mahrouki S, Naas T, Belhadj O. Dissemination and genetic support of broad-spectrum beta-lactam-resistant Escherichia coli strain isolated from two Tunisian hospitals during 2004- 
2012. Afri Health Sci. 2017;17(2): 346-355. https://dx.doi. org/10.4314/ahs.v17i2.8

8. Alabi OS, Mendonça N, Adeleke OE, Jorge da Silva G. Molecular screening of antibiotic-resistant determinants among multidrug-resistant clinical isolates of Proteus mirabilis from Southwest Nigeria. Afri Health Sci. 2017;17(2): 356-365. https://dx.doi.org/10.4314/ahs.v17i2.9

9 Hussein YM, Alhazmi A, Alzahrani S, El-Askary A, Alghamdy A, Bayomy E, Selim A, Alghamdy M. Osteopontin as a marker for response to Pegylated Interferon Alpha-2b treatment in Chronic HCV Saudi patients. Afri Health Sci. 2017;17(2): 366-372. https://dx.doi. org/10.4314/ahs.v17i2.10

10. Sungwa M, Susan T, Mikkel JC, Adolph KR, Boniface MS, Grundtvig TT, Ali S, Agertoug NM, Frederik SA. A VAR2CSA: CSP conjugate capable of inducing dual specificity antibody responses. Afri Health Sci. 2017;17(2): 373-381. https://dx.doi.org/10.4314/ahs.v17i2.11

11. Khalesi ZB, Simbar M, Azin SA. A qualitative study of sexual health education among Iranian engaged couples. Afri Health Sci. 2017;17(2): 382-390. https://dx.doi. org/10.4314/ahs.v17i2.12

12. Umar AS. Does female education explain the disparity in the use of antenatal and natal services in Nigeria? Evidence from demographic and health survey data. Afri Health Sci. 2017;17(2): 391-399. https://dx.doi. org/10.4314/ahs.v17i2.13

13. Machira K, Palamuleni M. Factors influencing women utilization of public health care services during childbirth in Malawi Public health facility utilization. Afri Health Sci. 2017;17(2): 400-408. https://dx.doi.org/10.4314/ahs. v17i2.14

14. Anyanwu M, Alida BWN. Uptake of long-acting reversible contraceptive devices in western region of The Gambia. Afri Health Sci. 2017;17(2): 409-417. https://dx. doi.org/10.4314/ahs.v17i2.15

15. Sengupta P, Nwagha U, Dutta S, Krajewska-Kulak E, Izuka E. Evidence for decreasing sperm count in African population from 1965 to 2015. Afri Health Sci. 2017;17(2): 418-427. https://dx.doi.org/10.4314/ahs.v17i2.16

16. Viljoen M, Claassen N. Allostatic load and heart rate variability as health risk indicators. Afri Health Sci. 2017;17(2): 428-435. https://dx.doi.org/10.4314/ahs. v17i2.17

17. Tufan A, Ilhan B, Bahat G, Karan MA. An under-diagnosed geriatric syndrome: sleep disorders among older adults. Afri Health Sci. 2017;17(2): 436-444. https://dx. doi.org/10.4314/ahs.v17i2.18

18. Bala W, Raquel D, Saraladevi N. Biochemical markers of mineral bone disorder in South African patients on maintenance haemodialysis. Afri Health Sci. 2017;17(2): 445-452. https://dx.doi.org/10.4314/ahs.v17i2.19

19. Rahamon SK, Fabian UA, Charles-Davies MA, Olaniyi JA, Fasanmade AA, Akinlade KS, Oyewole OE, Owolabi MO, adebusuyi JR, Hassan OO, Ajobo BM, Ebesunun MO, Adigun K, Popoola OO, Omiyale W, Arinola OG, Agbedana EO. Changes in mediators of inflammation and prothrombosis after 12 months of dietary modification in adults with metabolic syndrome. Afri Health Sci. 2017;17(2): 453-462. https://dx.doi.org/10.4314/ahs. v17i2.20

20. Kisozi T, Mutebi E, Kisekka M, Lhatoo S, Sajatovic M, Kaddumukasa M, Nakwagala FN, Katabira E. Prevalence, severity and factors associated with peripheral neuropathy among newly diagnosed diabetic patients attending Mulago hospital: a cross-sectional study. Afri Health Sci. 2017;17(2): 463-473. https://dx.doi.org/10.4314/ ahs.v17i2.21

21. Wang X, Lian Y, Wen X, Guo J, Wang Z, Jiang S, Hu Y. Expression of miR-126 and its potential function in coronary artery disease. Afri Health Sci. 2017;17(2): 474480. https://dx.doi.org/10.4314/ahs.v17i2.22

22. Opiro K, Wallis L, Ogwang M. Assessment of hospital-based adult triage at emergency receiving areas in hospitals in northern Uganda. Afri Health Sci. 2017;17(2): 481-490. https://dx.doi.org/10.4314/ahs.v17i2.23

23. Abu-Zidan FM. Distraction-related road traffic collisions. Afri Health Sci. 2017;17(2): 491-499. https://dx.doi. org/10.4314/ahs.v17i2.24

24. Luggya TS, Roche T, Ssemogerere L, Kintu A, Kasumba JM, Kwizera A, Tindimwebwa JVB. Effect of lowdose Ketamine on post-operative serum il-6 production among elective surgical patients: a randomized clinical trial. Afri Health Sci. 2017;17(2): 500-507. https://dx.doi. org/10.4314/ahs.v17i2.25

25. Nwosu C, Babalola MO, Ibrahim MH, Suleiman SI. Major limb amputations in a tertiary hospital in North Western Nigeria. Afri Health Sci. 2017;17(2): 508-512. https://dx.doi.org/10.4314/ahs.v17i2.26

26. Fadipe B, Oyelohunnu MA, Olagunju AT, Aina OF, Akinbode AA, Suleiman TF. Disordered eating attitudes: demographic and clinico-anthropometric correlates among a sample of Nigerian students. Afri Health Sci. 
2017;17(2): 513-523. https://dx.doi.org/10.4314/ahs. v17i2.27

27. Hammad LF, Benajiba N. Lifestyle factors influencing on bone health in young adult women in Saudi Arabia. Afri Health Sci. 2017;17(2): 524-531. https://dx.doi. org/10.4314/ahs.v17i2.28

28. Ren Y, Zhang M, Luo X, Zhao J, Yin L, Pang C, Feng T, Wang S, Wang B, Zhang H, Yang X, Hu D. Secular trend of the leading causes of death in China from 2003 to 2013. Afri Health Sci. 2017;17(2): 532-537. https://dx. doi.org/10.4314/ahs.v17i2.29

29. Titilayo A, Anuodo OO, Palamuleni ME. Family type, domestic violence and under-five mortality in Nigeria. Afri Health Sci. 2017;17(2): 538-548. https:/ /dx.doi. org/10.4314/ahs.v17i2.30

30. Ntodie M, Abu SL, Kyei S, Abokyi S, Abu EK. Near vision spectacle coverage and barriers to near vision correction among adults in the Cape Coast Metropolis of Ghana. Afri Health Sci. 2017;17(2): 549-555. https://dx. doi.org/10.4314/ahs.v17i2.31

31. Satte A, Kossoff EH, Belghiti M, Zerhouni A, Ouhabi H, Guerinech H, Mounach J. Why should modified Atkins diet be encouraged for treating epilepsy in emerging countries? Afri Health Sci. 2017;17(2): 556-558. https:// dx.doi.org/10.4314/ahs.v17i2.32

32. Shakir S, Ali N, Udin Z, Nazish H, Nabi M. Vitamin B6 and homocysteine levels in carbamazepine treated epilepsies of Khyber Pakhtunkhwa. Afri Health Sci. 2017;17(2): 559-565. https://dx.doi.org/10.4314/ahs. v17i2.33
33. Ran X, Zhang G, Li S, Wang J. Characterization and antitumor activity of camptothecin from endophytic fungus Fusarium solani isolated from Camptotheca acuminate. Afri Health Sci. 2017;17(2): 566-574. https://dx.doi. org/10.4314/ahs.v17i2.34

34. Animasahun VJ, Chapman HJ. Psychosocial health challenges of the elderly in Nigeria: a narrative review. Afri Health Sci. 2017;17(2): 575-583. https://dx.doi. org/10.4314/ahs.v17i2.35

35. Mwaka ES. Responsible conduct of research: enhancing local opportunities. Afri Health Sci. 2017;17(2): 584590. https://dx.doi.org/10.4314/ahs.v17i2.36

36. Alloh FT, Regmi PR. Effect of economic and security challenges on the Nigerian health sector. Afri Health Sci. 2017;17(2): 591-592. https://dx.doi.org/10.4314/ahs. v17i2.37

37. Chinniah KJ, Mody GM. Recovery from severe dysphagia in systemic sclerosis - myositis overlap: a case report. Afri Health Sci. 2017;17(2): 593-596. https://dx.doi. org/10.4314/ahs.v17i2.38

38. Tosepu R. Humidity is an ambient parameter to development of Zika virus: an Indonesian case. Afri Health Sci. 2017;17(2): 597-598. https://dx.doi.org/10.4314/ ahs.v17i2.39

39. Hashmi HJ, Javed H, Jamil N. Emerging epidemic of drug resistant tuberculosis in vulnerable population of developing countries. Afri Health Sci. 2017;17(2): 599-602. https://dx.doi.org/10.4314/ahs.v17i2.40 